\title{
Spontaneous remission of acromegaly: apoplexy mimicking meningitis or meningitis as a cause of apoplexy?
}

\author{
Remissão espontânea da acromegalia: meningite simulando \\ apoplexia ou meningite como causa da apoplexia?
}

Rocío Villar-Taibo', María D. Ballesteros-Pomar', Alfonso Vidal-Casariego', Rosa M. Álvarez-San Martín', Georgios Kyriakos', Isidoro Cano-Rodríguez'

1 Department of Endocrinology and Nutrition. Complejo Asistencial Universitario de León, León, Spain
Correspondence to: Rocío Villar-Taibo Complejo Asistencial Universitario de León, Department of Endocrinology and Nutrition Altos de Nava s/n 24008 - León, Spain rotaibo22@gmail.com

Received on Aug/9/2012 Accepted on May/9/2013

\section{SUMMARY}

Pituitary apoplexy is a rare but potentially life-threatening clinical syndrome characterized by ischemic infarction or hemorrhage into a pituitary tumor. The diagnosis of pituitary tumor apoplexy is frequently complicated because of the nonspecific nature of its signs and symptoms, which can mimic different neurological processes, including meningitis. Several factors have been associated with apoplexy, such as dopamine agonists, radiotherapy, or head trauma, but meningitis is a rarely reported cause. We describe the case of a 51-year-old woman with acromegaly due to a pituitary macroadenoma. Before surgical treatment, she arrived at Emergency with fever, nausea, vomiting and meningismus. Symptoms and laboratory tests suggested bacterial meningitis, and antibiotic therapy was initiated, with quick improvement. A computerized tomography (CT) scan at admission did not reveal any change in pituitary adenoma, but a few weeks later, magnetic resonance imaging (MRI) showed data of pituitary apoplexy with complete disappearance of the adenoma. Currently, her acromegaly is cured, but she developed hypopituitarism and diabetes insipidus following apoplexy. We question whether she really experienced meningitis leading to apoplexy or whether apoplexy was misinterpreted as meningitis. In conclusion, the relationship between meningitis and pituitary apoplexy may be bidirectional. Apoplexy can mimic viral or bacterial meningitis, but meningitis might cause apoplexy, as well. This fact highlights the importance of differential diagnosis when evaluating patients with pituitary adenomas and acute neurological symptoms. Arq Bras Endocrinol Metab. 2014;58(1):76-80

\section{SUMÁRIO}

A apoplexia é uma síndrome clínica rara, mas potencialmente fatal, caracterizada por infarto isquêmico ou hemorragia em um tumor pituitário. O diagnóstico de apoplexia de tumor pituitário é frequentemente complicado pela natureza inespecífica dos seus sinais e sintomas, que podem simular diferentes processos neurológicos, incluindo a meningite. Vários fatores estão associados com a apoplexia, como o uso de agonistas dopaminérgicos, radioterapia ou trauma da cabeça, mas a meningite foi raramente relatada. Descrevemos o caso de uma mulher de 51 anos de idade com acromegalia por um macroadenoma pituitário. Antes do tratamento cirúrgico, ela foi trazida ao pronto-socorro com febre, náusea, vômitos e meningismo. Os sintomas e análises laboratoriais sugeriram meningite bacteriana e o tratamento com antibióticos foi iniciado, com melhora rápida dos sintomas. Uma tomografia computadorizada (CT) na admissão ao hospital não revelou nenhuma alteração no adenoma pituitário, mas algumas semanas depois uma ressonância magnética (MRI) mostrou informações de apoplexia pituitária, com desaparecimento completo do adenoma. Atualmente, a acromegalia está curada, mas ela desenvolveu hipopituitarismo e diabetes insipidus depois da apoplexia. Questionamo-nos se a paciente realmente apresentou meningite que levou à apoplexia ou se a apoplexia foi mal interpretada como sendo meningite. A relação entre a meningite e a apoplexia pode ser bidirecional. A apoplexia pode simular a meningite viral ou bacteriana, mas a meningite também pode causar apoplexia. Esse fato enfatiza a importância do diagnóstico diferencial ao se avaliar pacientes com adenomas pituitários e sintomas neurológicos. Arq Bras Endocrinol Metab. 2014;58(1):76-80 


\section{INTRODUCTION}

$\mathrm{P}$ ituitary apoplexy is a syndrome characterized by ischemic infarction or hemorrhage into a pituitary tumor. It was first described by Bailey in 1898 (1), and it is an infrequent complication of these tumors. Although pituitary adenomas comprise approximately $10 \%$ of intracranial tumors, the incidence of apoplexy among them is low, ranging from $2 \%$ to $7 \%$ when clinical signs and surgical or histopathological evidence are considered (2).

The prevalence of apoplexy is similar among different subtypes of pituitary tumors, with a small increase in non-functioning adenomas and prolactinomas, especially in the fifth decade of life. This could be explained by the coincidence of the peak prevalence of pituitary apoplexy and non-functioning adenomas (3).

Several predisposing factors have been linked to apoplexy. Dopamine agonists, radiotherapy, recent surgery, trauma, or pituitary function tests are the most commonly described ones (2).

The diagnosis of this entity is often challenging. The typical presentation consists of sudden headache, visual disturbances, or a decrease in the level of consciousness, but pituitary apoplexy may resemble other intracranial pathological entities, such as meningitis, or it may even be clinically silent, being diagnosed only in MRI scans.

There have been several reports describing cases of hormonal remission of a functioning pituitary adenomas following apoplexy. However, spontaneous disappearance of the tumor has rarely been reported $(4,5)$.

We present a case of a patient with acromegaly who developed pituitary apoplexy after bacterial meningitis and who experienced a complete disappearance of the adenoma and remission of acromegaly.

\section{CASE REPORT}

A 51-year-old woman was referred to the Endocrinology Department after her rheumatologist noticed classic signs and symptoms of acromegaly. During the preceding months, the patient presented enlarged hands, increase in shoe size (4 sizes in two years), and craniofacial changes, such as nasal bone hypertrophy, macroglossia, and tooth separation. She also complained of arthralgia, weakness, carpal tunnel syndrome, frequent headaches, and amenorrhea.

Laboratory tests were performed with the following results: insulin-like growth factor I (IGF-1) $544 \mathrm{ng} /$
Ml (reference range: 60 to $200 \mathrm{ng} / \mathrm{mL}$ ); growth hormone $(\mathrm{GH}) 27.5 \mathrm{ng} / \mathrm{mL}$ (reference range: 0 to 10 $\mathrm{ng} / \mathrm{mL}$ ) with inadequate suppression to $19.9 \mathrm{ng} / \mathrm{mL}$ after a 75 -g oral glucose tolerance test. Prolactin was also slightly elevated: $89 \mathrm{ng} / \mathrm{mL}$ (reference range: 3 to $25 \mathrm{ng} / \mathrm{mL}$ ). Magnetic resonance imaging scan (MRI) confirmed the presence of a pituitary macroadenoma sized $1.6 \times 1.8 \mathrm{~cm}$ with right cavernous sinus invasion, but without optic chiasm compression (Figure 1).

After a complete evaluation, the patient was sent to the Neurosurgery Department to schedule surgical therapy for the macroadenoma. A few days before surgery, she arrived at the Emergency Department with a severe headache, phonophobia, photophobia, nausea, and vomiting. On examination, nuchal
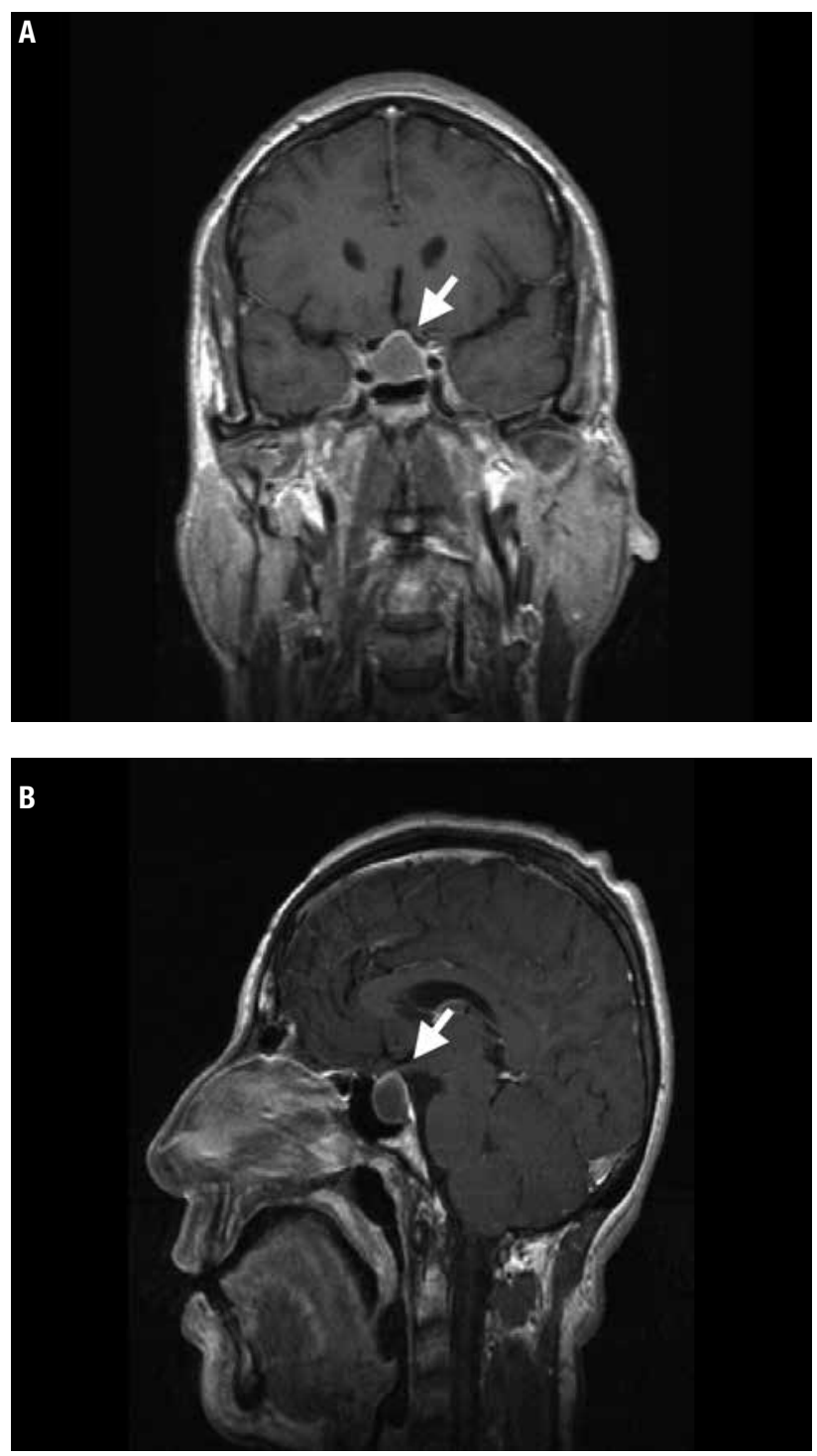

Figure 1. Pituitary MRI showing macroadenoma at diagnosis (arrows): (A) Coronal view of $\mathrm{T} 1$ weighted images. (B) Sagital view of $\mathrm{T} 1$ weighted images. 
rigidity and meningeal signs (Kernig and Brudzinski signs) were evidenced. Her temperature was $38^{\circ} \mathrm{C}$. A computerized tomography (CT) scan of her head showed no changes in the pituitary adenoma. An analysis of the cerebrospinal fluid (CSF) was consistent with bacterial meningitis (glucose level: $51 \mathrm{mg} / \mathrm{dL}$, protein concentration: $113 \mathrm{mg} / \mathrm{dL}$, and white blood cell count: 2,408 leucocytes $/ \mathrm{mm}^{3}, 98 \%$ neutrophils), although the CSF culture was sterile in the end.

Empiric antibiotic therapy with ceftriaxone and ampicillin was initiated with good response. Immediate clinical improvement was observed, and the headache, fever, and meningismus disappeared in a few days. After two weeks, the CSF was clear, with 10 leucocytes $/ \mathrm{mm}^{3}, 63 \mathrm{mg} / \mathrm{dL}$ of proteins, and $47 \mathrm{mg} /$ $\mathrm{dL}$ of glucose. Serum investigations revealed secondary hypothyroidism with thyroid stimulating hormone (TSH) $0.602 \mu \mathrm{U} / \mathrm{mL}$ (reference range: 0.2 to 4.5 $\mu \mathrm{U} / \mathrm{mL}$ ) and free T4 $0.592 \mathrm{ng} / 100$ (reference range: 0.9 to $1.7 \mathrm{ng} / \mathrm{l00}$ ), and the patient was discharged on levothyroxine therapy ( $50 \mu \mathrm{g}$ daily).

Due to the meningitis, neurosurgery was postponed until the patient completely recovered. A new pituitary MRI was performed 6 weeks after hospitalization, revealing hypersignal on $\mathrm{T} 2$-weighted sequences, suggesting chronic hemorrhage, and hypointense areas of necrosis on the left part of the sella turcica. No normal pituitary tissue was identified (Figure 2).

A diagnosis of pituitary apoplexy secondary to meningitis was suspected, and hormonal studies were repeated, confirming remission of the acromegaly, decreased pituitary function, as well as diabetes insipidus (IGF-1 $72.5 \mathrm{ng} / \mathrm{mL}$, GH $0.6 \mathrm{ng} / \mathrm{mL}$, TSH 0.036 $\mu \mathrm{U} / \mathrm{mL}$, free $\mathrm{T} 4 \mathrm{l} \mathrm{ng} / \mathrm{l} 00$, adrenocorticotrophic hormone $(\mathrm{ACTH})<10 \mathrm{pg} / \mathrm{mL}$ (reference range: 2 to $50 \mathrm{pg} / \mathrm{mL}$ ), basal cortisol $2.3 \mu \mathrm{g} / 100$ (reference range: 5 to $25 \mu \mathrm{g} / 100$ ), follicle-stimulating hormone (FSH) $3.89 \mathrm{mU} / \mathrm{mL}$ (reference range: 20 to 100 $\mathrm{mU} / \mathrm{mL}$ ), luteinizing hormone $(\mathrm{LH}) 1.15 \mathrm{mU} / \mathrm{mL}$ (reference range: $>20 \mathrm{mU} / \mathrm{mL}$, estradiol $<20 \mathrm{pg} / \mathrm{mL}$ (reference range: 0 to $30 \mathrm{pg} / \mathrm{ml}$ ) and prolactin 3.66 $\mathrm{ng} / \mathrm{mL}$ (reference range: 3 to $25 \mathrm{ng} / \mathrm{mL}$ ). She was put on hormonal replacement therapy with hydrocortisone (15 mg daily) and desmopressin (120 $\mu \mathrm{g}$ daily). The dose of levothyroxine was maintained, but sex hormone substitution was not considered due to her age.

At present, she remains asymptomatic, with marked improvement in the signs and symptoms of her previous acromegaly, including hand and foot size reduction,

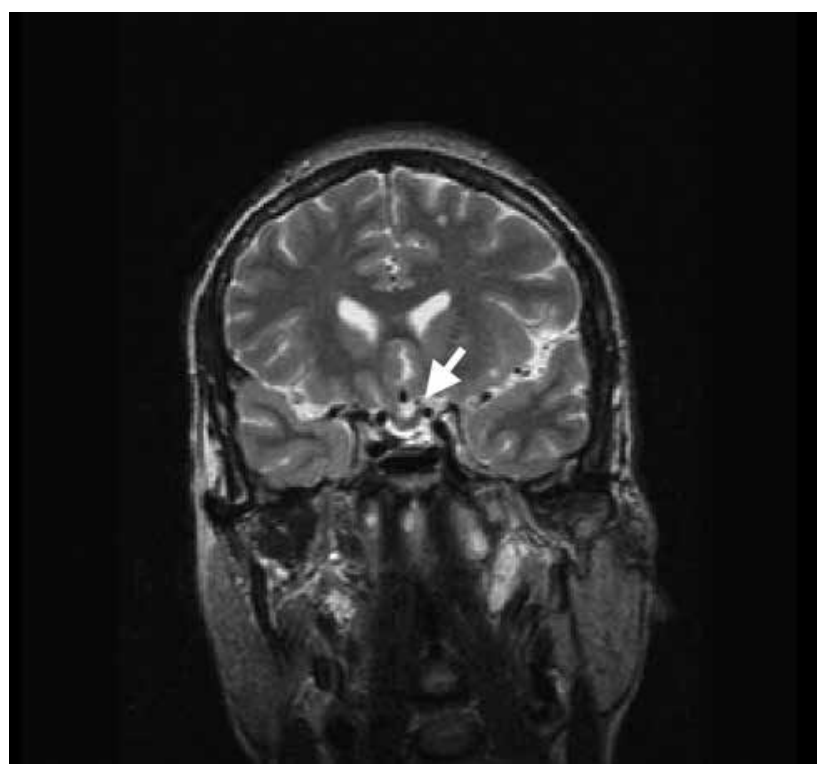

Figure 2. Pituitary MRI after meningitis (Coronal view of T2-weighted images) showing disappearance of macroadenoma (arrow).

absence of headaches, and amelioration of facial changes. Ophthalmological study results are normal. Hypopituitarism and diabetes insipidus still persist, but are well controlled with replacement therapy.

\section{DISCUSSION}

The atypical case we presented portrays spontaneous disappearance of $\mathrm{GH}$-secreting macroadenoma. Despite an initial diagnosis of meningitis, we question whether our patient really experienced meningitis leading to apoplexy, or if apoplexy was misinterpreted as meningitis.

To our knowledge, meningitis as a cause of apoplexy is rare. We only found one report in the literature describing remission of acromegaly following meningitis, but without complete disappearance of the tumor mass (6). Conversely, misdiagnose of pituitary apoplexy as viral or even bacterial meningitis has been published in several case reports (7-15). Pituitary apoplexy can produce chemical meningitis due to the release of debris through an aperture in the diaphragma sella into the CSF. The patient may develop fever, nuchal rigidity, and photophobia, simulating viral or, less frequently, bacterial meningitis. Minimal response to antimicrobial therapy should make us to reconsider meningitis, and think about the possibility of a pituitary apoplexy. The prompt recognition of apoplexy will enable the immediate initiation of steroid 
and fluid therapy, or decompression surgery, if needed. Immediate neurosurgical intervention is not mandatory in all patients, and the decision must be individualized. Several reports showed that conservative management can lead to a complete recovery of apoplexy in some cases (16).

In our case, both hypotheses, apoplexy mimicking bacterial meningitis or apoplexy caused by meningitis, could be possible. We cannot totally exclude any of them because the patient evolution presented controversial data.

On the one hand, clinical response to antibiotics would support the hypothesis of true meningitis. Thus, clinical recovery was evident on the first days of antibiotic treatment. Fever, nausea, and meningismus ceased after two days, and no corticoid treatment was needed. Initial CSF was compatible with bacterial meningitis, but CSF is rarely helpful in differentiating between diagnoses of apoplexy and meningitis.

On the other hand, the sudden onset of symptoms, especially headache, and the absence of microorganisms in the CSF culture may be more suggestive of apoplexy. However, it is well known that around $22 \%$ of bacterial meningitis cases are culture-negative, especially those associated with listeriosis (17). Thus, a sterile CSF would not rule out a bacterial meningitis diagnosis.

Differential diagnosis between pituitary apoplexy and other neurological conditions, like meningitis, requires a CT scan or a MRI, with the MRI being superior to CT for the diagnosis of pituitary apoplexy (sensitivity of $91 \%$ versus 28\%, respectively) (18). Some studies reported a $21 \%$ to $46 \%$ detection rate of apoplexy on CT scans, compared to $88 \%$ to $100 \%$ using MRIs $(19,20)$. MRI has greater sensitivity and tissue definition, with better detection of hemorrhage, edema of the pituitary gland, and necrosis. It is important to recognize apoplexy on CT scans, if hemorrhage or necrosis are apparent, as CT scans are usually the first neurological imaging performed in emergency departments. But, considering its low sensitivity, we should not reject the possibility of a pituitary tumor apoplexy if clinical assessment indicates this diagnosis.

Upon hospitalization, the CT scan of our patient did not reveal any change in the size or density of the adenoma. But a few weeks after the occurrence of meningitis, an MRI showed areas of hemorrhage and necrosis, suggesting apoplexy, with no evidence of macroadenoma or normal gland tissue.
The underlying mechanism behind the disappearance of a pituitary adenoma following apoplexy is poorly understood. When tumor size increases, compressing or outgrowing the nutrient vessels from hypophyseal arteries, the result may be ischemic necrosis, hemorrhage, and tumor apoplexy. It has been suggested that ischemic necrosis may be liquefied and absorbed, ultimately resulting in spontaneous resolution of adenoma (4).

Meningitis is not usually cited as inciting apoplectic episodes, but vasculopathy is a recognized complication of acute meningitis (2l). It remains unclear whether vasculitis due to the inflammatory infiltration of small vessels could be a mechanism of apoplexy in meningitis.

Finally, it is important to note that apoplexy prognoses have improved in the last decades. The majority of published series reports $60 \%$ of asymptomatic patients and $19 \%$ of patients with minor disabilities (22). More than half of all patients require hormone replacement following an episode of pituitary tumor apoplexy; therefore, endocrine monitoring is essential. Diabetes insipidus is uncommon (present in $2 \%$ to $3 \%$ of cases), perhaps due to different types of vascularization in the pituitary gland and the hypothalamus (2). Even though an MRI may indicate apparent complete disappearance of the adenoma, it is not likely that all the tumor cells have been fully destroyed, and there may be a risk of recurrence. If this is the case, these patients require careful follow-up (4).

In conclusion, the relationship between meningitis and pituitary apoplexy may be bidirectional. Apoplexy can mimic viral or bacterial meningitis but meningitis might cause apoplexy, as well. This fact highlights the importance of differential diagnosis when evaluating patients with pituitary adenomas and acute neurological symptoms.

Disclosure: no potential conflict of interest relevant to this article was reported.

\section{REFERENCES}

1. Bailey P. Pathological report of a case of acromegaly, with special reference to the lesions in the hypophysis cerebri and in the thyroid gland: and a case of hemorrhage into the pituitary. Philadelphia Med J. 1898;1:789-92.

2. Verrees M, Arafah BM, Selman WR. Pituitary tumor apoplexy: characteristics, treatment, and outcomes. Neurosurg Focus. 2004;16(4):1-7.

3. Chang CV, Felicio AC, Toscanini AC, Teixeira MJ, Cunha-Neto MB. Pituitary tumor apoplexy. Arq Neuropsiquiatr. 2009;67(2A): 328-33. 
4. Liu S, Wang X, Liu Y, Mao O. Spontaneous disappearance of the pituitary macroadenoma after apoplexy: a case report and review of the literature. Neurol India. 2012;60(5):530-2.

5. Fraser LA, Lee D, Cooper P, Van Uum S. Remission of acromegaly after pituitary apoplexy: case report and review of literature. Endocr Pract. 2009;15(7):725-31.

6. Katsuno M, Yamazaki M, Tahara S, Murai Y, Teramono A, Sano N. Spontaneous remission of acromegaly after meningitis: a case report. No To Shinkei. 2003;55(11):967-71.

7. Bjerrre $P$, Lindholm J. Pituitary apoplexy with sterile meningitis. Acta Neurol Scand. 1986;74(4):304-7.

8. Valente M, Marroni M, Stagni G, Floridi O, Perriello G, Santeusanio F. Acute sterile meningitis as a primary manifestation of pituitary apoplexy. J Endocrinol Invest. 2003;26(8):754-7.

9. Jassal DS, McGinn G, Embil JM. Pituitary apoplexy masquerading as meningoencephalitis. Headache. 2004;44(1):75-8.

10. Smidt $M H$, van der Vliet $A$, Wesseling $P$, de Vries J, TwicklerTB, Vos PE. Pituitary apoplexy after mild head injury misinterpreted as bacterial meningitis. Eur J Neurol. 2007;14(7):e7-8.

11. Chibarro S, Benvenuti L, Carnesecchi S, Faggionato F, Gagliardi R. An interesting case of a pituitary adenoma apoplexy mimicking an acute meningitis. Case report. J Neurosurg Sci. 2007;51(2):65-9.

12. Huang WY, Chien YY, Wu CL, Weng WC, Peng TI, Chen HC. Pituitary adenoma apoplexy with initial presentation mimicking bacterial meningoencephalitis: a case report. Am J Emerg Med. 2009;27(4):517e1-4.
13. Gómez Cuervo $C$, Kessler Sáiz P, Ruiz J, de Castro Martínez M. Febrile syndrome as a presentation form of pituitary adenoma. Rev Clin Esp. 2011;211(10):e66-e67.

14. Paisley AN, Syed AA. Pituitary apoplexy masquerading as bacterial meningitis. CMAJ. 2012;184(16):1812.

15. Cagnin A, MarcanteA, Orvieto E, Manara R. Pituitary tumor apoplexy presenting as infective meningoencephalitis. 2012;33(1):147-9.

16. Santos $A B$, França MM, Hirosawa RM, Marivo M, Zanini MA, Nunes VS. Conservative management of pituitary tumor apoplexy. Arq Bras Endocrinol Metab. 2011;55(5):345-8.

17. Hussein AS, Shafran SD. Acute bacterial meningitis in adults. $A$ 12-year review. Medicine (Baltimore). 2000;79(6):360-8.

18. Sibal L, Ball SG, Connolly V, James RA, Kane P, Kelly WF, et al. Pituitary apoplexy: a review of clinical presentation, management and outcome in 45 cases. Pituitary. 2004;7(3):157-63.

19. Bills DC, Meyer FB, Laws ER Jr, Davis DH, Ebersold MJ, Scheithauer BW, et al. A retrospective analysis of pituitary apoplexy. Neurosurgery. 1993;33(4):602-8.

20. Randeva HS, Schoebel J, Byrne J, Esiri M, Adams CB, Wass JA. Classical pituitary apoplexy: clinical features, management and outcome. Clin Endocrinol (Oxf). 1999;51(2):181-8.

21. Pfister HW, Borasio GD, Dirnagl U, Bauer M, Einhaupl KM. Cerebrovascular complications of bacterial meningitis in adults. Neurology. 1992;42(8):1497-504.

22. Semple PL, Webb MK, de Villiers JC, Laws ER Jr. Pituitary apoplexy. Neurosurgery. 2005;56(1):65-72. 